\title{
Selected IDS Output on sub-Saharan Africa 1981-85
}

1981

Bienefeld, M., 'Tanzanian industry and basic needs: short and long term issues', in Basic Needs in Danger: a Basic Needs Orientaled Strategy for Tanzania, ILO/JASPA, Addis Ababa

Bown, L., K. Lillis and J. Oxenham, Without Women No Developmen, Commonwealth Secretariat, London

Bown, L. and A. Little, 'Learning' in First Things First: Meeling the Basic Needs of the People of Nigeria. ILO/JASPA, Addis Ababa

Colclough, C., 'Dependent development in Southern Africa 1960-1980: national strategy options in a regional context', paper presented at a conference on Botswana's Economy Since Independence, National Institute of Development and Cultural Research, Gaborone, September

Crofton, H. E. M. and E. M. Godfrey, Training of Induswial Manpower: Siudy of Industrial Training in Kenya, TETOC/ British Council, London

Ellis, F., 'Agricultural pricing policy in Tanzania 1970-1979: implications for agricultural output, rural income, and crop marketing costs', ERB Paper, vol 80, no 2, University of Dar es Salaam

Godfrey, M., 'Kenya: Economic Prospects to 1985 ', EIU Special Repor, no 99, EIU, London

Harvey, C., Papers on the Economy of Borswana. Heinemann, London

de Kadt, E. and M. Segall (eds), 'Health needs and health services in rural Ghana', Social Science and Medicine, Special Issue, vol 15A no 4

Ministry of Health, (G. H. Bloom, N. H. Lenneiye, M. M. Segall and H. S. M. Ushewokunze, eds). 'Planning for equity in health: a sectoral review and policy statement', draft white paper prepared for the Government of Zimbabwe, Harare

Moore, M. et al., Small-holder Food Producrion in Tanzania, report to SIDA/Government of Tanzania
National Drugs and Therapeutics Policy Committee, (N. H Lenneiye and M. M. Segall, eds), 'The Pharmaceutical Sector in Zimbabwe: A Report to the Minister of Health', Harare

Oxenham, J. and A. Little, The Paper Qualification Sindrome and the Unemployment of School Leavers: The Cases of Ghana, Liberia, Sierra Leone, Tanzania, the Gambia, JASPA/ILO, Addis Ababa

Schaffer, B., African Public Management and Management Training, report to the World Bank, Washington, DC

Seers, D., First Things First: Meeting the Basic Needs of the People of Nigeria, United Printers Ltd. Addis Ababa, for the ILO

Segall, M. M. and A. White, "Research on primary health care: a multidisciplinary project in Ghana', World Heallh Forum, vol 2 no 3, pp341-6

\section{SIDA/IDS, East \& Southern African Agricultural Papers}

Somerset, H. C. A., Examination Reform: Some Lessons From Keny'a, World Bank, Washington

Swift, J., 'Seasonality in a West African pastoral society" in R. Chambers, R, Longhurst and A. Pacey (eds), The Seasonal Dimensions to Rural Poverty, Frances Pinter, London

\section{2}

Bennell, P., 'Professionalism: a case study of the pharmaceutical profession in Ghana", Social Science and Medicine, vol 16, pp601-7

- The colonial legacy of salary structures in anglophone Africa', Joumal of Modern African Sudies, vol 20 no 1 , pp 127-54

Bienefeld, M., 'Tanzania: model or anti-model?' in M. Bienefeld and M. Godfrey (eds), The Struggle for Development: National Strategies in an Internarional Contex, John Wiley, Chichester

- Evaluating Tanzanian industrial development between 1961-1978 in M. Fransman (ed), Indhestry and Accumularion in Africa. Heinemann, London

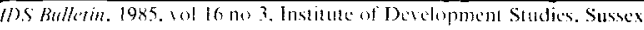


Boakye, J. K. A. and J. Oxenham, 'The Quality of Education in Ghanaian Middle Schools', Research Report, IDS, Sussex

Chambers, R., 'Rural refugees in Africa: past experience, future pointers', Disasters, vol 6, no 1, pp21-30

Colclough, C. and P. Fallon, 'Rural poverty in Botswana: dimensions, causes and constraints', in D. Ghai and S. Radwan (eds), Agrarian Policies and Rural Poverty in Africa, ILO, Geneva

Daniel, P., Employment, Basic Needs and Poverty Alleviation: Issues and Prospects in the Current Economic Crisis, background report to 1LO/JASPA, for the 6th African Regional Labour Conference 1983, Addis Ababa

Godfrey, M., 'Kenya: African capitalism or simple dependence?' in M. Bienefeld and M. Godfrey (eds), The Struggle for Development: National Strategies in an International Context, John Wiley, Chichester

Green, R., 'Agricultural crisis in sub-Saharan Africa: capitalism and transitions to socialism', IDS Bulletin, vol 13 no 4, IDS, Sussex

- A time of struggle: endogenous shocks, structural transformation and crisis in Tanzania', Millennium Journal of International Studies, vol 10 no 1

- 'Southern African Development Coordination: the struggle continues' in Africa Contemporary Record 1980-81, Africana, New York, ppA24-A34

Harvey, C., 'Living on capital: Africa in the 1980s', South, December

Little, A., 'The content analysis of examinations in eight African countries: an overview' in Paper Qualification Syndrome and Unemployment of School Leavers, 1LO/ JASPA, Addis Ababa

Luckham, R., 'African/Arab/OECD military relations: the recycling of imperialism' in D. Wai (ed), Interdependence in a World of Unequals: African/Arab/OECD Economic Cooperation for Development, Westview Press, Boulder, Colorado

Stevens, C., 'Nigeria: economic prospects to 1985 after the oil glut', EIU Special Report no 123, ElU, London

Thomson, A. with others, 'Nutritional status indicators, interpretation and policy making role', Food Policy, vol 7 no 2 , pp $99-112$

\section{3}

Allison, C. and R. Green (eds), 'Accelerated Development in sub-Saharan Africa: what agendas for action? IDS Bulletin vol 14 no I, IDS, Sussex

Colclough, C. with P. Olsen, Review of Incomes Policy in Botswana: 1972-83, Ministry of Finance and Development Planning, Gaborone
Daniel, P. with M. Faber et al, Report to the Government of Ghana on Revisions to the Mining Tax Regime

Godfrey, M., 'The Professions in Africa; some interactions between local and international markets', Development and Change, vol 14 no 3, pp373-402

-with others, $A$ World of Differentials: African Pay Structures in a Transnational Context, Hodder and Stoughton, London in association with IDRC, Ottawa

Green, R., 'Political-economic adjustment and IMF conditionality: Tanzania 1974-1981', in J. Williamson (ed), IMF Conditionality, Institute for International Economics, Washington

-'Southern Africa: what kind of dialogue? What chance of sustained cooperation?' in C. Stevens (ed), EEC and the Third World: A Survey 3, Hodder and Stoughton for ODI London/IDS Sussex

- Southern African development cooperation: from dependence and poverty towards economic liberation' in C. Legum (ed), Africa Contemporary Record 1981-82, Africana, New York and London

-“"No worst there is none?": Tanzanian political economic crisis 1978-??' in J. Carlsson (ed), Recession in Africa, Scandinavian Institute of African Studies, Uppsala, pp 173-203

Lipton, M., 'African agricultural development: the EEC's new role?' Development Policy Review, vol l, pp l-2 I and Bulletin vol 14 no 3, IDS, Sussex pp2l-3l

Luckham, R., 'Political and social problems of development' in Africa South of the Sahara 1983-84, Europa Publications Ltd, London

- 'Security and disarmament in Africa', Alternatives vol 9 no 2

Segall, M., 'Planning and politics of resource allocation for primary health care: promotion of meaningful national policy', Social Science and Medicine, vol 17 no 24, pp 147-60, also published in P. Oberender et al (eds), Health and Development in Africa, Lang, Frankfurt am Main

-with C. Marzagao, 'Drug selection: Mozambique', World Development, vol 11 no 3 (special issue), pp205-16, also published in S. Patel (ed), Pharmaceuticals in the Third World, Pergamon Press, Oxford

Stevens, C., 'The European Community and Africa, the Caribbean and the Pacific', in J. Lodge (ed), Institutions and Policies of the European Community, Frances Pinter, London

Swift, J., (ed), Pastoral Development in Central Niger, Ministry of Rural Development and USAID, Niamey, Niger

Thomson, A., 'Somalia: food aid in a long term emergency', Food Policy, vol 8 no 3, pp209-19

White, C., The Transformation of Agrarian Systems in Centrally Planned Economies in Africa, Report to the FAO, Rome 


\section{4}

Allison, C., 'What Alternatives for Women in Africa' in P. Ndegwa, L. P. Mureithi and R. Green (eds), Development Options for Africa in the 1980s and Beyond, Society for International Development, Kenya

Boakye, J. K. A., 'Unemployment among Elementary School Leavers in Ghana and its Solution through Vocationalisation of Formal Education: An Evaluation of the Continuation School System', DPhil thesis, University of Sussex

Colclough, C. with P. Daniel and M. Godfrey, 'Response' in J. Sender and S. Smith, 'What's Right with the Berg Report and What's Left of its Critics?', Discussion Paper 192, IDS, Sussex

Daniel, P., 'The economy of Zambia' in Africa South of the Sahara 1984-85, Europa Publications, London

-with R. Green and M. Lipton, 'Towards a strategy for the rural poor in sub-Saharan Africa', Discussion Paper 193, IDS, Sussex

Fortin, C., 'Energy' in Zambia: Restructuring in the Midst of Crisis, Report of the Zambia Public Investment Mission

Green, R., 'A natural pair for cooperation', in ICDA New's, Special Report - Southern Africa, March

- 'Tanzania: sparring with the IMF', Africa Report, vol 29 no 5, pp71-74

-with S. Griffith-Jones, African External Debt and Development: a review and analysis, African Centre for Monetary Studies, Dakar

-with H. W. Singer, 'Sub-Saharan Africa in Depression: the impact on the welf are of children', World Development, vol 12 no 3 pp283-296 and in R. Jolly and G. A. Cornia (eds), The Impact of World Recession on Children, Pergamon, Oxford

Lipton, M. with C. Heald, 'The European Community and African Food Strategies', CEPS Working Document (Economics), no 12, Centre for European Policy Studies, Brussels

Longhurst, R., The Energy Trap: Work, Nutrition and Child Malnutrition in Northern Nigeria, Cornell International Nutrition Monograph Series, Number 13

Luckham, R., "Foreign powers and militarism in the Horn of Africa' Revieu of African Political Economy, nos 30 \& 31
Moore, M., Options in Tanzania's Agriculture, Report to SIDA, Stockholm

Oxenham, J., Evaluation Report on the Practical Subjects Project, Zambia, 1974-1984, FINNIDA, Helsinki

- Planning Continuing Education for Uganda. 1985-1989, Report to Centre for Continuing Education. Makerere University and British Council, London

Stevens, C., The Political Economy of Nigeria, Economist Publications, London

Swift, J., with A. Maliki, A Cooperative Development Experiment among Nomadic Herders in Niger, paper 18C, Pastoral Development Network, Agricultural Administration Unit, ODI, London

\section{5}

Green, R. H., 'African External Debt and Development: Context Strategy and Tactics for the 1980s', African Centre for Monetary Studies, Dakar

-(ed), 'Sub-Saharan Africa: towards oblivion or reconstruction?', Journal of Development Planning, no 15, United Nations, New York

House of Commons, Foreign Affairs Committee, Famine in Africa, House of Commons Paper 56, HMSO, London (includes memoranda by Caroline Allison, W. Carden, Robert Chambers, Edward Clay, Reginald Green, Simon Maxwell, H. W. Singer, Kate Young and Tony Leeks)

Rose, T. (ed), Crisis and Recovery in sub-Saharan Africa: Complexities and Realities, OECD Development Centre, Paris (includes papers by Mike Faber, Christopher Colclough, Michael Lipton, Caroline Allison, Ralph Miller, Philip Daniel, Martin Godfrey, Reginald Green, Stephany Griffith-Jones)

Singer, H. W., 'The African Food Crisis and the Role of the African Development Bank' in Proceedings of a symposium held in Tunis, May 1984, African Development Bank, Abidjan

White, C. Pelzer, The Role of Cooperative Agriculture in Transforming Labour Relations and Gender Relations: Experiences from the Green Zones, Maputo, Mozambique, Report to SIDA, Stockholm

C.A. 


\section{Books Received}

J. H. W. Holden and J. T. Williams (eds), Crop Genetic Resources: Conservation and Evaluation, George Allen \& Unwin, London, 1984

Development Southern Africa, vol 1 nos 3\& 4, November 1984

M. Konno and H. Usui, Basic Information for the Case Study of Eleventh RECA Seminar in Aomori Prefecture, Japan, Afro-Asian Rural Reconstruction Organisation, New Delhi, 1983

Douglas E. Horton, Social Scientists in Agricultural Research: lessons from the Mantaro Valley Project, Peru, IDRC, Ottawa, 1984

Robert J. Moore, Third-World Diplomats in Dialogue with the First World, IDRC/Macmillan, 1985

J. Sholto Douglas and Robert A. de J. Hart, Forest Farming: lowards a solution 10 problems of world hunger and conservation, Intermediate Technology Publications, London, 1984

Iftikhar Ahmed and Bill H. Kinsey (eds), Farm Equipment Innovations in Eastern and Central Southern Africa (an ILO/WEP study), Gower, 1984

V. N. Balasubramanyam, The Economy of India, Weidenfeld and Nicolson, London, 1985

Guy Standing (ed), Labour Circulation and the Labour Process (an ILO/WEP study), Croom Helm, London, 1984

Hanne Christensen, Afghan Refugees in Pakistan: from emergency towards self-reliance, UNRISD, Geneva, 1984

Najib M. Assifi and James H. French, Guidelines for Planning Communication Support for Rural Development Campaigns, UNDP/DTCP, Bangkok, 1984

S. Neil MacFarlane, Superpower Rivalry and Third World Radicalism, Croom Helm, Beckenham, 1985

Pranab K. Bardhan, Land, Labor, and Rural Poverty: essays in development economics, Columbia University Press, New York, 1984

Albert O. Hirschman, Getting Ahead Collectively: grassroots experiences in Latin America, Pergamon Press, New York, 1984

Patrick McAuslan, Urban Land and Shelter for the Poor, Earthscan/IIEO, London and Washington DC, 1985

J. G. M. Hilhorst and M. Klatter (eds), Social Development in the Third World: level of living indicators and social planning, Croom HeIm, Beckenham, 1985

D. P. Chaudhri and Ajit K. Dasgupta, Agriculture and the Development Process, Croom Helm, Beckenham, 1985
S. H. Ominde (ed), Population and Development in Kenya, Heinemann, London, 1984

I. J. Barwell, G. A. Edmonds, J. D. G. F. Howe and J. de Veen, Rural Transport in Developing Countries, Intermediate Technology Publications, London, 1985

S. La-Anyane, Economics of Agricultural Development in Tropical Africa, John Wiley and Sons, Chichester, 1985

Mats Lundahl (ed), The Primary Sector in Economic Development: Proceedings of the Seventh Arne Ryde Symposium, Frostavallen, August 29-30 1983, Croom Helm, Beckenham, 1985

Michael Smith, Jane McLoughlin, Peter Large and Rod Chapman, Asia's New Industrial World, Methuen, London and New York, 1985

S. O. Adjare, Try the Rabbit: a handbook on rabbit raising for beginners, TCC/Intermediate Technology Publications, London, 1984

Waclaw Micuta, Modern Stoves for All, Intermediate Technology Publications/Bellerive Foundation, London, 1985

Jean Stubbs, Tobacco on the Periphery: a case study in Cuban labour history, 1860-1958, CUP, 1985

Institute of Social Studies, Research Outputs: Annotated Bibliography 1977-1984, The Hague, 1984

Kirsten Westergaard, State and Rural Society in Bangladesh: a study in relationship, Curzon Press, London, 1985

Robin Clarke (ed), Wood-Stove Dissemination: Proceedings of the Conference held at Wolfheze, The Netherlands, Intermediate Technology Publications, London, 1985

John A. R. Miles (ed), Public Health Progress in the Pacific: Geographical Background and Regional Development, D. Rendel, Dordrecht (Netherlands)

Diffusion of Biomass Energy Technologies in Developing Countries (2nd edition), National Academy Press, Washington DC, 1984

Jeff Kenna and Bill Gillett, Solar Water Pumping: $A$ Handbook, Intermediate Technology Publications, London, 1985

Patrick McAuslan, Urban Land and Shelter for the Poor, Earthscan, London, 1985

Appropriate Technology Institutions: a Directory (revised edition), ITDG, London, 1985

Angela Sinclair, $A$ Guide to Appropriate Technology Institutions, ITDG, London, 1984

Susan B. Rifkin, Health Planning and Community Participation: Case Studies in South-East Asia, Croom Helm, London, 1985 
Gordon Hathway, Low-Cost Vehicles: Options for moving people and goods, Intermediate Technology Publications, London, 1985

Small Hydro Power in China: A Survey, prepared by Hangzhou Regional Centre (Asia Pacific) for Small Hydro Power, Intermediate Technology Publications, London, 1985
Arnold Pacey and Philip Payne (eds), Agricultural Development and Nutrition, Hutchinson for the FAO and UNICEF, London, 1985

Paul Richards, Indigenous Agricultural Revolution, Hutchinson, London, 1985

How to Make the Most of your Tractor, Introduced by Professor Brian May, Intermediate Technology Publications, London, 1985 